\title{
Penguatan Kebijakan One Health dan Jejaring Laboratorium Dalam Deteksi Dini Leptospirosis di Indonesia
}

\section{STRENGTHENING ONE HEALTH POLICY AND LABORATORY NETWORK TO LEPTOSPIROSIS EARLY DETECTION IN INDONESIA}

\author{
Farida Dwi Handayani, Diana Andriyani Pratamawati, Wening Widjajanti, Arief Mulyono, Arum Sih \\ Joharina, Muhidin, Bernadus Yuliadi, Aprilia Safitri, dan Nur Hidayati, Ristiyanto \\ Balai Besar Penelitian dan Pengembangan Vektor dan Reservoir Penyakit \\ Jl. Hasanudin No.123 Salatiga, Jawa Tengah, Indonesia \\ *Email : farida.litbangkes@gmail.com
}

Submitted: 09-09-2019, Revised:16-09-2019, Revised:11-11-2019, Accepted : 27-11-2019

\begin{abstract}
International Leptospirosis Society stated Indonesia as a country with high leptospirosis incidence and ranked third in the world for mortality. Rikhus Vektora, in 2015 - 2017 in 25 provinces in Indonesia, showed that positive leptospirosis rats were found in all regions. However, Health Service Providers (PPK) both at the basic and advanced levels stated that they were unable to carry out a diagnosis of leptospirosis cases. Meanwhile, the data also showed that in the provinces where no leptospirosis cases reported, there were Leptospira bacteria found in captured rats both in settlements and remote areas. This condition causes leptospirosis like the phenomenon of the iceberg that is seen as no cases while the facts in the field of many people infected with late treatment. One Health approach in cross-sector leptospirosis data integration from a related department is needed in determining priorities for the prevention of leptospirosis. It is necessary to establish a laboratory network to obtain faster information regarding the enforcement of the diagnosis of leptospirosis cases. The proposed policy recommendations are the discovery of leptospirosis cases with capacity building for doctors and health workers through clinical lectures, cross-sector joint surveillance, and strengthening of laboratory networks for early enforcement of leptospirosis diagnose.
\end{abstract}

Keywords: leptospirosis, one-health, laboratory, early detection, Indonesia

\begin{abstract}
Abstrak
International Leptospirosis Society menyatakan Indonesia sebagai negara dengan insidens leptospirosis tinggi dan peringkat ketiga dunia untuk mortalitas. Hasil Riset Khusus Vektor dan Reservoir Penyakit (Rikhus Vektora) pada tahun 2015 - 2017 di 25 provinsi di Indonesia menunjukkan bahwa di setiap provinsi ditemukan persentase tikus positif bakteri Leptospira. Namun, penyedia Pelayanan Kesehatan (PPK) baik yang ada di tingkat dasar maupun lanjutan menyatakan belum mampu untuk melakukan penegakkan diagnosa kasus leptospirosis. Sementara itu, data juga menunjukkan bahwa pada beberapa provinsi yang menyatakan tidak ada kasus leptospirosis ditemukan adanya bakteri Leptospira pada tikus yang ditangkap baik pada ekosistem yang dekat dengan pemukiman maupun yang jauh dari pemukiman. Kondisi ini menyebabkan leptospirosis seperti fenomena gunung es yaitu terlihat tidak ada kasus sementara fakta di lapangan banyak orang terjangkit yang terlambat diobati. Pendekatan 'One Health' dalam integrasi data leptospirosis lintas sektor (Dinas Kesehatan, Dinas Peternakan, Dinas Pertanian) diperlukan dalam penentuan prioritas penanggulangan leptospirosis. Selain itu, perlu dibuat jejaring laboratorium agar didapatkan informasi lebih cepat terkait penegakan diagnosis kasus leptospirosis. Rekomendasi kebijakan yang diusulkan adalah penemuan kasus leptospirosis dengan capacity building dokter dan tenaga kesehatan dengan cara ceramah klinis, surveilans bersama lintas sektor dan penguatan jejaring laboratorium untuk penegakan dini diganosa leptospirosis.
\end{abstract}

Kata kunci: leptospirosis, one-health, laboratorium, deteksi dini, Indonesia 


\section{PENDAHULUAN}

Leptospirosis merupakan penyakit yang paling luas penyebarannya di dunia, ahli leptospirosis dunia, Adler, menyampaikan bahwa leptospirosis ditemukan di semua benua kecuali Antartika. ${ }^{1}$ Bakteri Leptospira dapat menginfeksi sedikitnya 160 spesies mamalia, antara lain anjing, babi, sapi, kuda, kucing, dan marmot. Binatang pengerat terutama tikus merupakan reservoir reservoir yang paling utamautama. Pada tubuh tikus bakteri Leptospira akan menetap dan membentuk koloni serta berkembang biak di dalam epitel tubus ginjal tikus dan secara terus menerus dikeluarkan melalui urin. Leptospirosis bersifat musiman, di daerah beriklim sedang masa puncak insidens dijumpai pada musim panas dan musim gugur karena temperatur adalah faktor yang mempengaruhi kelangsungan hidup Leptospira, sedangkan di daerah tropis insidens tertinggi terjadi selama musim hujan. International Leptospirosis Society menyatakan Indonesia sebagai negara dengan insidens leptospirosis tinggi dan peringkat ketiga dunia untuk mortalitas. Kasus leptospirosis dKasus leptospirosis di Indonesia ditemukan di DKI Jakarta, Jawa Barat, Jawa Tengah, DI Yogyakarta, Lampung, Sumatera Selatan, Sumatera Barat, Sumatera Utara, Kalimantan Timur, dan Kalimantan Barat. Leptospirosis termasuk reemerging disease, sehingga sewaktu-waktu dapat muncul secara sporadik serta berpotensi untuk menimbulkan kejadian luar biasa (KLB). Penyakit ini termasuk re-emerging disease, sehingga sewaktu-waktu dapat muncul secara sporadik serta berpotensi untuk menimbulkan kejadian luar biasa (KLB).

Proses alur penularan leptospirosis dapat dilihat pada Gambar 1. Leptospirosis termasuk penyakit yang kembali muncul (reemerging) karena urbanisasi, pemanasan global dan kejadian-kejadian ekstrim seperti banjir dan tanah longsor. ${ }^{2,3}$

Berdasarkan data Sub-direktorat Zoonosis, P2TVZ Kementerian Kesehatan, pada tahun 2017 di Indonesia dilaporkan 908 kasus leptospirosis dengan kematian 136 orang (CFR 14,98\%). Sedangkan Pusat Data dan Informasi Kementerian Kesehatan Republik Indonesia mencatat bahwa pada 2014 - 2017 kematian akibat leptospirosis masih diatas 10\%. Berturutturut pada tahun 2014 terdapat 550 kasus dan 61 meninggal (11,09\%); tahun 2015 ada 366 kasus dan 65 meninggal (17,76\%); 2016 dilaporkan 343 kasus 47 meninggal (CFR 13,70\%). Leptospirosis terbukti menjadi ancaman bukan hanya bagi kesehatan manusia tetapi juga hewan kesayangan dan hewan ternak. Data dari Balitvet Bogor menunjukkan bahwa rata rata infeksi Leptospira pada sapi $19 \%$, tikus $29 \%$, dan anjing 45\%. Serovar dominan pada hewan adalah Bataviae, Hardjo, Tarassovi, Rachnmati dan Bankinang. Data dari Balitvet Bogor menunjukkan bahwa rata rata infeksi Leptospira pada sapi 19\%, tikus 29\%, dan anjing 45\%. Serovar dominan pada hewan adalah Bataviae, Hardjo, Tarassovi, Rachnmati dan Bankinang. Ancaman ini menjadi momentum bagi Dinas Kesehatan dan Dinas Peternakan dan Pertanian untuk berkoordinasi lintas sektor dalam merespon dengan lebih efektif dalam penanggulangan leptospirosis. Langkah awal dalam proses kerjasama lintas sektor adalah identifikasi bahwa leptospirosis menjadi masalah dan membutuhkan perhatian yang cukup besar sehingga masing-masing sektor akan fokus menggunakan sumber daya keuangan dan personel yang terbatas secara efektif. ${ }^{4}$

Mis-diagnosis dan under-reported kasus leptospirosis juga masih menjadi masalah di Indonesia. Diagnosis leptospirosis ini rumit dan sering keliru di diagnosa dengan penyakit lain, misalnya malaria, typhoid, influenza, demam dengue, hepatitis dan meningitis, sehingga menyebabkan misdiagnosis. Sementara keberhasilan pengobatan leptospirosis sangat tergantung pada diagnosis dini. Kasus yang dilaporkan mungkin masih sangat rendah dari kondisi riil di lapangan. Misdiagnosis dan keterlambatan diagnosis dini menyebabkan pasien leptospirosis terlambat ditangani dengan tepat. Dokter dan tenaga laboratorium kesehatan belum terpapar dengan baik dengan leptospirosis sebagai salah satu analisis diagnosisnya. Kemampuan laboratorium di Indonesia dalam pemeriksaan leptospirosis juga belum merata, hal ini menyebabkan kasus leptospirosis banyak yang tak terdeteksi. 
Kajian ini bertujuan untuk memperkuat kebijakan penanggulangan leptospirosis dengan pendekatan yang lebih tepat, efektif dan efisien. Sehingga kejadian leptospirosis di Indonesia dapat dicegah dan tidak mewabah, mengingat faktor risiko leptospirosis di Indonesia sangat mendukung kejadian leptospirosis. Akan dibahas lebih lanjut mengenai diskripsi model pendekatan One Health yaitu integrasi data sebagai bentuk kerjasama lintas sektor dalam penanggulangan leptospirosis secara terpadu dan bentuk jejaring laboratorium dalam mendeteksi bakteri leptospira baik pada manusia, hewan ternak maupun hewan peliharaan.

Kajian ini diharapkan dapat menjadi bahan masukan bagi pembuat kebijakan dalam penanggulangan leptospirosis khususnya bagi program (sub-direktorat zoonosis, P2PTVZ), dan Dinas Kesehatan baik Provinsi maupun Kabupaten/Kota.

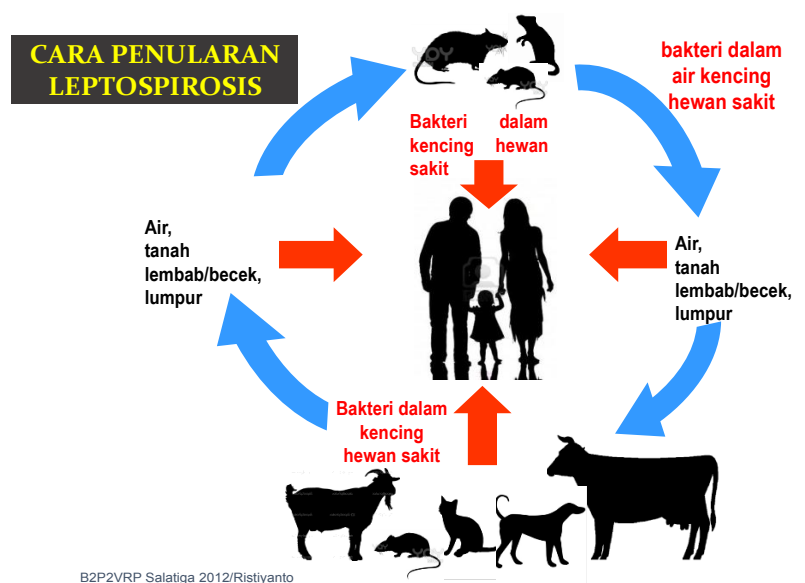

Gambar 1 . Alur penularan leptospirosis

\section{BAHAN DAN METODE}

Metode yang digunakan adalah studi literatur dan konfirmasi lapangan dengan pendekatan kualitatif. Pendekatan kualitatif menekankan pada makna dibalik semuanya, definisi suatu situasi tertentu (dalam konteks tertentu). Pendekatan kualitatif lebih mementingkan proses daripada hasil akhir, oleh karena itu urut-urutan kegiatan dapat berubah-rubah tergantung pada kondisi dan banyaknya gejalagejala yang ditemukan. ${ }^{5}$

Ciri-ciri dari analisis data dalam peneltian kualitatiif adalah ${ }^{5}$ :
1. Data dikumpukan tanpa intrumen.

2. Data muncul dalam bentuk kata-kata.

3. Bukan keputusan apriori dalam penyajian data.

4. Data bisa dalam bentuk macam- macam, bisa catatan lapangan, dokumen, catatan interview, rekaman tape, dan artifak.

5. Tabulasi dibatasi untuk membantu pengenalan pola, digunakan untuk mendukung pemaknaan kualitatif.

6. Makna diambil dan strategi kualitatif, sebagai peneliti yang terjun ke lapangan. Analisis data kualitatif adalah berupa uraian dalam betuk prosa kemudian dikaitkan dengan data lainnya untuk mendapatkan kejelasan terhadap suatu kebenaran atau sebaliknya, sehingga memperoleh gambaran baru ataupun menguatkan gambaran-gambaran yang sudah ada.

Sumber data kajian berupa laporan hasil penelitian Rikhus Vektora 2015-2017 dan penelitian-penelitian leptospirosis lainnya yang mendukung. Konfirmasi ke lapangan dilakukan untuk memperoleh kebenaran data. Pada penelitian ini, konfirmasi lapangan untuk melakukan pendekatan one health dalam deteksi dini leptospirosis dilakukan dengan Focus Group Discussion di salah satu wilayah Rikhus Vektora yang ditemukan yaitu Kabupaten Kulonprogo Provinsi Daerah Istimewa Yogyakarta.

Kajian dilakukan di Balai Besar Penelitian dan Pengembangan Vektor dan Reservoir Penyakit Salatiga. Kajian dilakukan dari bulan Juli hingga Oktober 2018. Pelaksanaan Focus Group Discussion (FGD) penanggulangan leptospirosis lintas sektor dilakukan di Kabupaten Kulonprogo sebagai sampel terpilih.

\section{Hasil Kajian Literatur dan Data Sekunder Kebijakan One Health 'One Health' adalah pendekatan untuk}

merancang dan menerapkan program, kebijakan, perundang-undangan dan penelitian dimana berbagai sektor berkomunikasi dan bekerja sama untuk mencapai hasil kesehatan masyarakat yang lebih baik.

Area kerja dimana pendekatan One Health sangat relevan bukan hanya dalam penanggulangan leptospirosis saja, tetapi juga 
zoonosis lain seperti rabies, flu dan anthraks, termasuk keamanan makanan serta dalam pencegahan resistensi antibiotik (ketika bakteri berubah setelah terkena antibiotik dan menjadi lebih sulit diobati). ${ }^{4}$

Pada penularan leptospirosis, bakteri Leptospira patogenik menginfeksi hewan dan manusia, dimana bakteri ini memiliki ekosistem yang sama untuk hidup dan bersirkulasi. Upaya salah satu sektor saja tidak dapat mencegah atau menanggulangi penyebaran leptospirosis. Pendekatan 'One Health' atau lintas sektor dalam penanggulangan leptospirosis diperlukan, termasuk jejaring laboratorium ini diharapkan bisa didapatkan informasi lebih cepat terkait penegakan diagnosis kasus leptospirosis.

Balai Besar Penelitian dan Pengembangan Vektor dan Reservoir Penyakit (B2P2VRP) merupakan Unit Pelaksana Teknis (UPT) Badan Penelitian dan Kesehatan Kementerian Kesehatan yang memiliki tanggung jawab dalam penelitian pengendalian zoonosis telah melakukan penelitian mendalam terkait faktor resiko, epidemiologi dan deteksi leptospirosis. Pendekatan komprehensif dalam penanggulangan leptospirosis sangat penting dalam pemutusan rantai penularan, terutama pada saat terjadi peningkatan kasus atau kejadian luar biasa (KLB) leptospirosis. Gambaran penanggulangan leptospirosis secara komprehensif hasil penelitian B2P2VRP dapat dlihat pada Gambar 2.

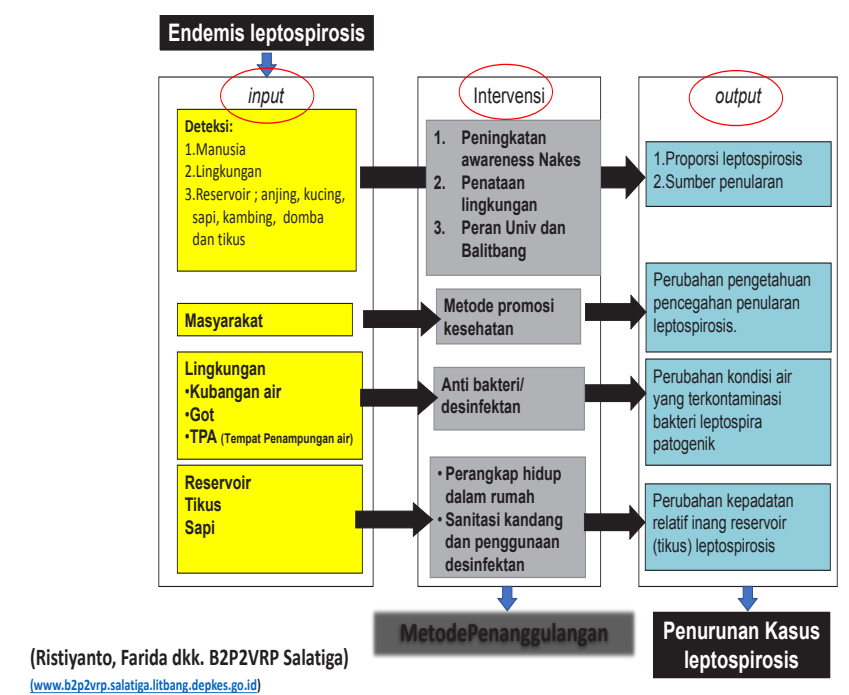

Gambar 2. Model Pengendalian Leptospirosis Hasil Penelitian B2P2VRP 20042018
Klinisi, paramedis, dan dokter hewan merupakan garda depan atau front line pada penanggulangan leptospirosis, karena dari merekalah kasus suspek leptospirosis ditegakkan. Adanya kasus suspek akan berlanjut dengan manajemen kasus dan lingkungan, terutama pada saat KLB. Epidemiolog dan peneliti serta analis di laboratorium juga memiliki peranan yang sangat penting dalam pemutusan rantai penularan, yaitu dengan menyajikan hasil laboratorium yang terpercaya dan analisa hasil serta pengendalian yang tepat. Kerjasama dan komunikasi yang baik dari ketiga kelompok tersebut akan sangat mengefisienkan kinerja One Health. $^{6}$

Sedangkan untuk membangun kerangka konsep One Health dalam deteksi dini leptospirosis, diperlukan tahapan berikut dengan mengadopsi dari teori prioritas zoonosis menggunakan One Health. ${ }^{4}$

\section{SITUASI LEPTOSPIROSIS}

Laporan terbaru menunjukkan bahwa leptospirosis terjadi di seluruh dunia dan menjadi beban penyakit dan risiko terhadap kesehatan manusia. Diperkirakan lebih dari 1 juta kasus leptospirosis berat dan sekitar 60.000 kematian akibat penyakit ini per tahun. Dengan demikian, beban leptospirosis sebanding dengan, atau lebih tinggi dari, penyakit tropis penting lainnya yang terabaikan, seperti demam berdarah akut. ${ }^{7}$

Sejak tahun 1936 telah dilaporkan leptospirosis di Indonesia dengan mengisolasi serovar leptospira, baik dari hewan liar maupun hewan peliharaan. Secara klinis leptospirosis pada manusia telah dikenal sejak tahun 1892 di Jakarta oleh Van der Scheer. Namun, isolasi baru berhasil dilakukan oleh Vervoort pada tahun 1922. Pada tahun 1970an, kejadian pada manusia dilaporkan Fresh, di Sumatera Selatan, Pulau Bangka serta beberapa rumah sakit di Jakarta. Tahun 1986, juga dilaporkan hasil penyelidikan epidemiologi di Kuala Cinaku Riau, ditemukan serovar pyrogenes, semaranga, rachmati, icterohaemorrhagiae, hardjo, javanica, ballum dan tarassovi. ${ }^{8}$

Situasi Leptospirosis di Indonesia selama tahun 2014 - 2017 terdapat enam provinsi yang 
melaporkan adanya kejadian leptospirosis, yaitu DKI Jakarta, Jawa Barat, Jawa Tengah, Daerah Istimewa Yogyakarta, Jawa Timur, Banten dan Kalimantan Selatan., ${ }^{9}, 10$ Data kasus, kematian Case Fatality Rate (CFR) penyakit leptospirosis di Indonesia selama tahun 2014 - 2017 pada dilihat pada Tabel 1.

Leptospirosis mulai menjadi wabah yang menakutkan di Indonesia tercatat sejak tahun 2002. Saat itu terjadi Kejadian Luar Biasa (KLB) leptospirosis di wilayah Jakarta dan Bekasi.

Pada awal tahun 2002, dimana terjadi banjir yang menggenangi beberapa wilayah di Ibukota Jakarta, telah terjadi kejadian luar biasa (KLB) Leptospirosis dan dilaporkan olehRumah Sakit Tarakan Jakarta sebanyak 21 orang meninggal dunia (CFR 20\%) dari 103 orang penderita yang dirawat di rumah sakit. Angka kematian ini cukup tinggi disebabkan oleh terlambatnya penderita datang ke rumah sakit. Untuk mengantisipasi terjadinya KLB leptospirosis, sejak tahun 2003 telah dikeluarkan buku pedoman diagnosa dan penatalaksanaan kasus penanggulangan leptospirosis di Indonesia oleh Sub Zoonosis, Direktorat Jenderal Pemberantasan Penyakit Menular, Kementerian Kesehatan. ${ }^{11}$

Berdasarkan data tahun 2013 hingga 2018, di Berdasarkan data tahun 2013 hingga 20Indonesia, leptospirosis tersebar di Propinsi Jawa Barat, Jawa Tengah, Daerah Istimewa Yogyakarta (DIY), Lampung, Sumatera Utara, Sumatera Barat, Sumatera Selatan, Riau, Bali, Nusa Tenggara Barat, Sulawesi Utara, Sulawesi Selatan, Kalimantan Timur, dan Kalimantan Barat .${ }^{1213}$ Jumlah pasien laki-laki dengan leptospirosis lebih tinggi dibandingkan perempuan. Hal ini mungkin mencerminkan paparan dalam kegiatan yang didominasi laki-laki. Untuk alasan yang sama, laki-laki remaja dan setengah baya memiliki prevalensi lebih tinggi dibandingkan anak laki-laki dan orang usia lanjut. ${ }^{14}$ Angka kematian akibat leptospirosis di Indonesia termasuk tinggi, mencapai $2,5 \%-16,4 \%$ dan hal ini tergantung sistem organ yang terinfeksi. Pada penderita usia lebih dari 50 tahun kematian mencapai 56\%.

Satu penelitian di Srilanka, negara tetangga yang memiliki problem leptospirosis seperti Indonesia menyatakan bahwa deteksi yang paling efektif dilakukan untuk deteksi leptospirosis adalah perpaduan antara MAT dan PCR. Akan tetapi PCR lebih sensitive dibandingkan MAT dan ELISA. ${ }^{15}$ Pada harihari pertama penyakit, uji yang tepat adalah PCR. Di negara-negara berkembang, biaya dan persyaratan untuk peralatan khusus dan keahlian teknis tetap sebagai kendala performa uji ini. Seperti di kebanyakan daerah endemik, pengujian molekuler tidak tersedia dalam praktik umum, konfirmasi diagnosis tidak dapat diperoleh dengan cepat. Dari minggu kedua pada penyakit, serologi diagnosis didasarkan pada deteksi IgM spesifik. Jika memungkinkan, semua tes serologis dapat dilakukan, terutama MAT; tetapi bila tidak memungkinkan uji laboratorium, RDT dapat dilakukan. ${ }^{16}$

Ada lebih dari 230 serovar yang diketahui dalam genus Leptospira. Diagnosis serologis konfirmasi leptospirosis biasanya dilakukan dengan menggunakan uji aglutinasi mikroskopis (MAT) yang bergantung pada penggunaan kultur hidup sebagai sumber antigen, yang seharusnya dilakukan dengan menggunakan panel perwakilan antigen dari serovars lokal. Teknik lain, seperti uji immunosorbent assay (ELISA) dan slide tes aglutinasi (SAT), dapat mendeteksi berbagai kelas antibodi tetapi mungkin dapat terjadi reaksi positif palsu dan memerlukan konfirmasi hasil ini oleh MAT. ${ }^{17}$

Satu riset nasional Badan Penelitian dan Pengembangan Kesehatan Kementerian Kesehatan RI, yaitu Riset Khusus Vektor dan Reservoir Penyakit Riset Khusus Vektor dan Reservoir Panyakit (Rikhus Vektora) merupakan salah satu riset nasional untuk mengetahui gambaran vektor dan reservoir penyakit di Indonesia. Tujuan pelaksanaan Rikhus Vektora ini adalah untuk pemuktahiran data vektor dan reservoir penyakit secara nasional sebagai dasar pengendalian penyakit tular vektor dan reservoir (new emerging dan re-emerging diseases) di Indonesia. Salah satu penyakit yang diteliti pada sampel Rikhus Vektora adalah leptospirosis.

Hasil Rikhus Vektora yang dilakukan yang dilakukan Badan Litbang Kesehatan pada 25 
provinsi di Indonesia((2015-2017)) menunjukkan bahwa di di semua provinsi ditemukan tikus positif pembawa bakteri Leptospira dengan variasi jenis serovar tertentu tertentu (Tabel 2). Selain itu Selain itu Rikhus Vektora juga membuktikan bahwa serovar yang ada pada tikus identik dengan serovar yang umumnyanya ditemukan pada kasus leptospirosis di manusia. Jenis serovar Leptospira patogenik pada tikus hasil Rikhus Vektora saat itu saat itu antara lain serovar bataviae (bat), canicola (can), djasiman (dja), icterohaemorrhagie (ict), manhao (man), hardjo (hardjo), robinsoni (rob), hebdomadis (heb), mini (mini), griphotyposa (gri), bankinang (ban), pomona (pom), sarmin (sar), pyrogenes (pyr), rama (rama) . Hasil selengkapnya dapat dilihat pada Tabel 2.

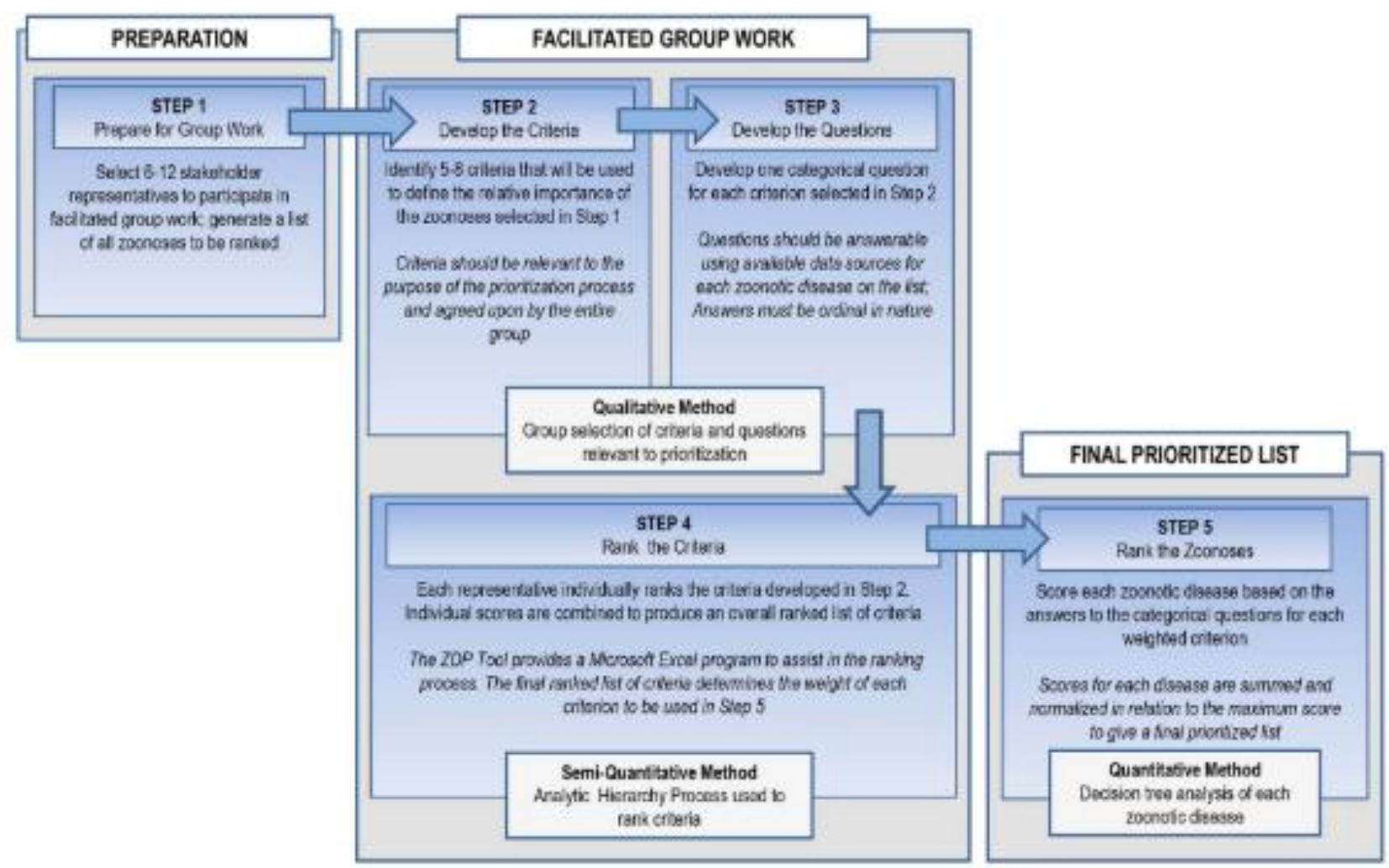

Gambar 3. Lima Langkah Proses Prioritisasi dengan Pendekatan One Health dalam Penanggulangan Zoonosis (doi:10.1371/journal.pone.0109986.g001)

Tabel 1. Jumlah Kasus, Meninggal dan Case Fatality Rate (CFR) Leptospirosis menurut Provinsi Tahun 2014 - 2017 di Indonesia 9,10

\begin{tabular}{|c|c|c|c|c|c|c|c|c|c|c|c|c|}
\hline \multirow{2}{*}{ Provinsi } & \multicolumn{3}{|c|}{2014} & \multicolumn{3}{|c|}{2015} & \multicolumn{3}{|c|}{2016} & \multicolumn{3}{|c|}{2017} \\
\hline & $\mathbf{K}$ & M & CFR & $\mathbf{K}$ & M & CFR & $\mathbf{K}$ & $\mathbf{M}$ & CFR & $\mathbf{K}$ & M & CFR \\
\hline DKI Jakarta & 106 & 18 & 16,98 & 37 & 4 & 10,81 & 39 & 0 & 0,00 & 1 & 0 & 0,00 \\
\hline Jawa Barat & 26 & - & - & 2 & 1 & 50,00 & 16 & 2 & 12,50 & 5 & 0 & 0,00 \\
\hline Jawa Tengah & 198 & 32 & 16,16 & 149 & 24 & 16,11 & 164 & 30 & 18,29 & 316 & 51 & 16,14 \\
\hline DI Yogyakarta & 154 & 9 & 5,84 & 144 & 19 & 13,19 & 17 & 6 & 35,29 & 123 & 24 & 19,51 \\
\hline Jawa Timur & 61 & 2 & 3,28 & 3 & 0 & 0,00 & 102 & 6 & 5,88 & 106 & 19 & 17,92 \\
\hline Banten & 0 & - & - & 31 & 17 & 54,84 & 5 & 3 & 60,00 & 89 & 14 & 15,73 \\
\hline Kalimantan Selatan & 5 & 1 & 20,00 & 0 & 0 & 0 & 0 & 0 & 0 & - & - & - \\
\hline
\end{tabular}

Keterangan : $\mathrm{K}=$ Kasus, $\mathrm{M}=$ Mati, $\mathrm{CFR}=$ Case Fatality Rate 
Tabel 2. Jenis Serovar Leptospira Patogenik Pada Tikus Tertangkap di Tiap Provinsi Hasil Rikhus Vektora 2015-2017.18-43

\begin{tabular}{|c|c|c|c|c|c|c|c|c|c|c|c|c|c|c|c|c|c|}
\hline NO & Provinsi & bat & can & dja & ict & $\operatorname{man}$ & hardjo & rob & heb & $\operatorname{mini}$ & gri & ban & pom & Sar & pyr & rama & $\begin{array}{c}\Sigma \\
\text { serovar }\end{array}$ \\
\hline 1 & Aceh & & $*$ & $*$ & & $*$ & & $*$ & $*$ & & & & & & & & 5 \\
\hline 2 & $\begin{array}{l}\text { S u m a t e ra } \\
\text { Barat }\end{array}$ & $*$ & $*$ & $*$ & & & & & & & $*$ & & & & & & 4 \\
\hline 3 & Jambi & $*$ & $*$ & $*$ & $*$ & & $*$ & $*$ & $*$ & & $*$ & & & & & & 8 \\
\hline 4 & Riau & & & $*$ & $*$ & & & & & & $*$ & $*$ & & & & & 4 \\
\hline 5 & $\begin{array}{l}\text { S u m a t e r a } \\
\text { Selatan }\end{array}$ & & $*$ & & $*$ & $*$ & & & & & & & & & & & 3 \\
\hline 6 & $\begin{array}{l}\text { B a n } \mathrm{g} \mathrm{k} \text { a } \\
\text { Belitung }\end{array}$ & $*$ & $*$ & & & & & & & & & $*$ & $*$ & & & & 4 \\
\hline 7 & Lampung & & $*$ & $*$ & & & & & $*$ & $*$ & $*$ & & & $*$ & & & 6 \\
\hline 8 & Jawa Barat & $*$ & & $*$ & $*$ & & & & & & $*$ & & & & & & 4 \\
\hline 9 & Banten & * & $*$ & $*$ & $*$ & $*$ & & $*$ & $*$ & & & $*$ & & $*$ & & & 9 \\
\hline 10 & Jawa Tengah & & $*$ & $*$ & $*$ & & & & & & & & & & & & 3 \\
\hline 11 & $\begin{array}{l}\text { D I } \\
\text { Yogyakarta }\end{array}$ & $*$ & $*$ & $*$ & $*$ & & & $*$ & $*$ & * & $*$ & & & & & & 8 \\
\hline 12 & Jawa Timur & & & $*$ & & & & & $*$ & & & & & & & & 2 \\
\hline 13 & $\begin{array}{l}\text { Kalimantan } \\
\text { Selatan }\end{array}$ & & $*$ & $*$ & $*$ & & & & $*$ & & $*$ & $*$ & & & & & 6 \\
\hline 14 & $\begin{array}{l}\text { Kalimantan } \\
\text { Tengah }\end{array}$ & $*$ & & $*$ & $*$ & $*$ & & & & & & & & & & $*$ & 5 \\
\hline 15 & $\begin{array}{l}\text { Kalimantan } \\
\text { Barat }\end{array}$ & & $*$ & $*$ & $*$ & & $*$ & & & & & $*$ & & & $*$ & & 6 \\
\hline 16 & Bali & & & & $*$ & $*$ & & $*$ & $*$ & & & & & & & & 4 \\
\hline 17 & NTT & & $*$ & $*$ & $*$ & & & & & & & $*$ & & & & & 4 \\
\hline 18 & NTB & & & $*$ & $*$ & $*$ & & $*$ & $*$ & & * & $*$ & $*$ & $*$ & & & 9 \\
\hline 19 & $\begin{array}{l}\text { S u l a w e s i } \\
\text { Utara }\end{array}$ & * & $*$ & $*$ & $*$ & & & & * & & & & & & & & 5 \\
\hline 20 & $\begin{array}{l}\text { S u l a w e s i } \\
\text { Tenggara }\end{array}$ & $*$ & & $*$ & $*$ & & & & $*$ & & $*$ & $*$ & & & & & 6 \\
\hline 21 & $\begin{array}{l}\text { S u l a w e s i } \\
\text { Tengah }\end{array}$ & & $*$ & & $*$ & & $*$ & & & & & & & & & & 3 \\
\hline 22 & $\begin{array}{l}\text { Sulawesi Se- } \\
\text { latan }\end{array}$ & & & $*$ & $*$ & & & & & & $*$ & & & & & & 3 \\
\hline 23 & Maluku & - & - & - & - & - & - & - & - & - & - & - & - & - & - & - & 0 \\
\hline 24 & $\begin{array}{l}\text { M a } 1 \mathrm{u} \mathrm{k} \mathrm{u} \\
\text { Utara }\end{array}$ & $*$ & $*$ & $*$ & & & & $*$ & & & $*$ & $*$ & & & & & 6 \\
\hline 25 & Papua & & $*$ & $*$ & $*$ & $*$ & & & & & & & & & & & 4 \\
\hline 26 & Papua Barat & $*$ & $*$ & $*$ & $*$ & $*$ & & $*$ & $*$ & & $*$ & & & $*$ & & $*$ & 10 \\
\hline
\end{tabular}

Berdasarkan hasil pengumpulan data sekunder Rikhus Vektora, diketahui bahwa tidak semua provinsi memiliki data leptospirosis. Pencatatan dan pelaporan kasus leptospirosis perlu diseragamkan dan ditingkatkan. Penyedia Pelayanan Kesehatan (PPK) baik yang ada di tingkat dasar maupun lanjutan menyatakan belum mampu untuk melakukan penegakkan diagnosa kasus leptospirosis.

Hasil pemeriksaan laboratorium pada sampel darah dan ginjal tikus pada Rikhus Vektora menyatakan bahwa pada beberapa provinsi yang menyatakan tidak ada kasus leptospirosis ditemukan adanya bakteri Leptospira pada tikus yang ditangkap baik pada ekosistem yang dekat dengan pemukiman, maupun yang jauh dari pemukiman.

\section{Pemeriksaan Laboratorium Leptospirosis}

Pemeriksaan leptospirosis di RS atau puskesmas umumnya menggunakan Rapid Diagnostic Tes (RDT) berbasis antibodi, deteksi yang sering terlambat untuk mendiagnosis. ${ }^{44}$ RDT berbasis antibodi hanya dapat efektif digunakan setelah lima bahkan sembilan hari dari onset penyakit, yaitu ketika titer antibody mulai 
muncul, dan sering menyebabkan mis-diagnosis sehingga dapat terjadi keparahan atau organ failure pada pasien. Sedangkan pemeriksaan dini infeksi Leptospira hanya dapat dilakukan di laboratorium dengan peralatan canggih dengan metode molekuler (PCR). Pemeriksaan gold standard leptospirosis adalah Microscopic Agglutination Test (MAT) yang hanya dapat dilakukan oleh beberapa laboratorium saja di Indonesia (Tabel 4). Pemeriksaan MAT ini dapat mengindikasikan spesifik jenis serovar yang menginfeksi. Akan tetapi, terdapat perbedaan jumlah dan jenis serovar yang dimiliki oleh setiap laboratorium tersebut, baik RS. Dr. Kariadi, BBlitvet Bogor dan B2P2VRP Salatiga, sehingga akan menyebabkan hasil dan interpretasi yang berbeda dalam pemeriksaan. Disisi lain, pemeriksaan PCR leptospirosis sangat unik, ada beberapa catatan dari pengalaman mendeteksi Leptospira yang harus diperhatikan bagi laboratorium lain yang juga melakukan pemeriksaan PCR. Informasi dan berbagi pengalaman dalam deteksi leptospirosis sangat penting, sehingga jejaring laboratorium dibutuhkan untuk dapat saling memberikan informasi dan berbagi pedoman pemeriksaan yang telah terbukti efektif untuk mendeteksi leptospirosis secara tepat serta peningkatan kapasitas laboratorium.

Penanggulangan leptospirosis di Indonesia muncul akibat beberapa hal antara lain gejala yang non-spesifik, sistem surveilans yang kurang dan belum adanya tes diagnosis dini yang cepat dan sederhana, sedangkan pemeriksaan konfirmasi laboratorium di Indonesia banyak tantangan dan hanya dapat dilakukan di beberapa laboratorium. Leptospirosis dapat diobati dengan antibiotik, diagnosis yang benar dan cepat, serta, serta diferensial diagnosal diagnosa dari penyakit lain membantu dalam manajemen yang efektif bagi bagi pasien. Pengetahuan tentang seroepidemiologi lokal penyakit ini juga membantu program kesehatan untuk melakukan tindakan kuratif serta pencegahan. ${ }^{49}$

\section{Tabel 3. Jenis Tikus Positif Terinfeksi Serovar Leptospirosis Patogenik Hasil Rikhus Vektora} $2015-2017^{18-43}$

\begin{tabular}{|c|c|c|}
\hline Kelompok/Type Tikus & Spesies Tikus & Jenis Ekosistem \\
\hline $\begin{array}{l}\text { Tikus Domestik } \\
\text { (dekat pemukiman }\end{array}$ & $\begin{array}{l}\text { Rattus tanezumi } \\
\text { Rattus norvegicus } \\
\text { Rattus nitidus }\end{array}$ & $\begin{array}{l}\text { Hutan Dekat Pemukiman } \\
\text { Pantai Dekat Pemukiman } \\
\text { Non Hutan Dekat Pemukiman }\end{array}$ \\
\hline Tikus Peridomestik & $\begin{array}{l}\text { Rattus argentiventer } \\
\text { Rattus exulans } \\
\text { Rattus tiomanicus } \\
\text { Rattus hoffmani }\end{array}$ & Hutan dan Non Hutan \\
\hline $\begin{array}{l}\text { Tikus sylvatik } \\
\text { (jauh pemukiman) }\end{array}$ & $\begin{array}{l}\text { Bunomys chrysocomus } \\
\text { Bunomys penitus } \\
\text { Maxomys whiteheadi } \\
\text { Leopoldamys diwangkarai } \\
\text { Sundamys muelleri } \\
\text { Melomys Bennisteri }\end{array}$ & $\begin{array}{l}\text { Hutan Jauh Pemukiman } \\
\text { Pantai Jauh Pemukiman } \\
\text { Non Hutan Jauh Pemukiman }\end{array}$ \\
\hline \multicolumn{3}{|c|}{$\begin{array}{l}\text { Tabel 4. Laboratorium pemeriksa leptospirosis dengan metode Microscopic Agglutination Tes } \\
\text { (MAT) sebagai gold standard pemeriksaan leptospirosis* }\end{array}$} \\
\hline \multicolumn{2}{|c|}{ Institusi / laboratorium } & Jumlah serovar \\
\hline \multicolumn{2}{|l|}{ RSUP Dr. Kariadi Semarang } & 30 serovar \\
\hline \multicolumn{2}{|c|}{ Balai Besar Litbang Veteriner (BBalitvet) Bogor } & 13 serovar \\
\hline \multicolumn{2}{|c|}{ Balai Besar Litbang Vektor dan Reservoir Penyakit (B2P2VRP) Salatiga } & 15 serovar \\
\hline
\end{tabular}


Apabila dilihat dari sisi peraturan perundangan, pengelolaan dan pengendalian leptospirosis telah rinci tersedia baik dari Kementerian Kesehatan maupun Kementerian Pertanian. Akan tetapi sinergi dari keduanya masih dibutuhkan. Beberapa peraturan terkait dengan leptospirosis telah disusun oleh bidang kesehatan dan pertanian yaitu :

1. Undang-Undang Republik Indonesia Nomor 18 Tahun 2009 tentang Peternakan dan Kesehatan Hewan. ${ }^{50}$

2. Peraturan Presiden Republik Indonesia Nomor 30 Tahun 2011 tentang Pengendalian Zoonosis. ${ }^{51}$

3. Peraturan Menteri Kesehatan Republik Ind o ne sia Nomor 1501 / M E K K S / $\mathrm{PER} / \mathrm{X} / 2010$ tentang Jenis Penyakit Menular Tertentu yang Dapat Menimbulkan Wabah dan Upaya Penanggulangan. ${ }^{52}$

4. Peraturan Menteri Kesehatan Republik Indonesia Nomor 5 Tahun 2014 tentang Panduan Praktik Klinis Bagi Dokter di Fasilitas Pelayanan Kesehatan Primer. ${ }^{53}$

5. Peraturan Menteri Kesehatan Republik Indonesia Nomor 82 Tahun 2014 tentang Penanggulangan Penyakit Menular.

6. Keputusan Menteri Pertanian Nomor : 206/ $\mathrm{kpts} / \mathrm{tn} .530 / 3 / 2003$ tentang Penggolongan Jenis-Jenis Hama Penyakit Hewan Karantina, Penggolongan dan Klasifikasi Media Pembawa.

7. Keputusan Menteri Pertanian Republik Indonesia Nomor 4971/Kpts/OT.140/12/2013 tentang Penetapan Zoonosis Prioritas.

8. Surat Edaran Direktur Jenderal Pencegahan dan Pengendalian Penyakit Nomor HK.02.01/ IV/151/2017 tentang Kewaspadaan Kejadian Luar Biasa Leptospirosis.

9. Peraturan Kementerian Kesehatan (PMK) No.658 Tahun 2009 tentang Jejaring Laboratorium Diagnosis penyakit Infeksi New-Emerging dan Re-Emerging.

Kegiatan Focus Group Discussion (FGD) telah dilakukan oleh B2P2VRP Salatiga untuk mempertemukan pertemukan Dinas Kesehatan, Dinas Peternakan dan Pertanian, Tokoh masyarakat dan PKK di Kabupaten Kulonprogo, DIY untuk berdiskusi dalam pengendalian leptospirosis di wilayahnya. Hasil FGD menunjukkan bahwa memang belum ada keterpaduan sistem dan kerjasama antara DKK dan Dinkeswan Kulonprogo dengan melibatkan masyarakat dalam penanggulangan leptospirosis. Perlu adanya kerjasama lintas sektor dalam pengendalian leptospirosis.

\section{Pengendalian Tikus Reservoir Leptospirosis}

Leptospirosis ditularkan melalui kontak dengan air, 1 lumpur, tanaman yang telah dicemari oleh air seni dari rodent (tikus) dan hewan lain yang mengandung bakteri Leptospira. ${ }^{54}$

Leptospirosis umumnya menyerang para petani, pekerja perkebunan, pekerja tambang/ selokan, pekerja rumah potong hewan dan militer Leptospirosis dapat menyebabkan kematian namun juga dapat diobati. ${ }^{54}$

\section{PEMBAHASAN \\ Analisis Gap}

Leptospirosis jarang dimasukkan sebagai diagnosis banding dalam anamnese pasien dengan gejala mirip typhoid, demam dengue/demam berdarah dengue atau malaria. Penyakit ini sering mis-diagnosis karena gejala klinis pasien leptospirosis sangat bervariasi, dari infeksi tanpa gejala, sindrom mirip flu, sampai leptospirosis berat dengan kerusakan kerusakan multi-organ yang dapat menyebabkan kematian. Awareness tenaga kesehatan puskesmas dan RS (paramedis) serta dokter perlu ditingkatkan dalam upaya penemuan atau diagnosa penemuan/diagnosa kasus leptospirosis. Karena leptospirosis termasuk dalam termasuk dalam neglected disease atau penyakit terabaikan dan kasusnya merupakan fenomena gunung es di Indonesia. Jumlah kasus yang dilaporkan masih sedikit dari jumlah kasus sesungguhnya di lapangan.

Masih terjadi mis-integrasi data dan komunikasi lintas sektor dalam pengendalian leptospirosis. Masih terjadi mis-integrasi data dan komunikasi lintas sektor dalam pengendalian leptospirosis. Data tersebar pada masingmasing Dinas, Kementerian dan Lembaga. Perbedaan penempatan leptospirosis sebagai penyakit prioritas di masing-masing kementerian menyebabkan perbedaan sudut pandang dalam menempatkan penyakit ini sebagai prioritas yang harus ditanggulangi. Direktorat Jenderal Pencegahan dan Pengendalian Penyakit (P2P) Kementerian Kesehatan khususnya Sub Direktorat Zoonosis membutuhkan data 
komprehensif dalam rangka penanggulangan leptospirosis dengan tepat.

Deteksi dan pemeriksaan laboratorium leptospirosis masih sangat lemah di Indonesia. Pemeriksaan cepat yang ada saat ini adalah rapid tes (RDT) berbasis antibody detection. RDT ini tidak selalu ada di setiap puskesmas atau RS, kalaupun ada jarang sekali digunakan karena diagnosis atau anamnese dokter dan paramedis tidak mengarah ke leptospirosis (hasil supervisi Penelitan Surveilans Letospirosis 2018). RDT ini efisien digunakan bila titer antibody pasien (IgM) muncul dan cukup untuk dideteksi. Umumnya titer antibody pasien muncul pada hari ke-5 setelah onset penyakit atau bahkan lebih tergantung kondisi tubuh pasien. Bila RDT digunakan dibawah hari ke-5, maka dapat menyebabkan hasil terbaca negatif palsu. Terkait hal ini, kembali kita kepada gap \#1, bahwa belum semua klinisi memahami hal ini.

Disisi lain, dengan adanya sifat bakteri yang mudah menghindari sistem imun tubuh dan cepat sekali berpindah masuk ke jaringan, terkadang kurang dari 5 hari dapat menyebabkan kerusakan organ. Maka deteksi infeksi dini leptospirosis yang paling tepat adalah dengan mengenali atau mendeteksi antigen (bakteri Leptospira) pada fase akut atau dibawah 5 hari pada pasien. Saat ini metode yang dapat digunakan pada fase akut adalah metode molekuler dengan polymerase chain reaction (PCR). Akan tetapi PCR ini jarang ada di puskesmas dan RS tipe C dan D. pada RS tipe B dimungkinkan ada, tetapi jarang mengarah untuk deteksi leptospirosis. Deteksi PCR leptospirosis hanya pada laboratorium khusus yang melakukan, itupun dengan metode yang berbeda-beda karena penggunaan primer dan prosedur yang berbeda. Sehingga hasilnya pun dapat berbeda.

Jejaring laboratorium diagnosis penyakit infeksi new-emerging dan re-emerging telah diatur berdasarkan Peraturan Menteri Kesehatan Republik Indonesia nomor 658/Menkes/Per/ VIII/2009. Akan tetapi dalam pelaksanaannya belum diatur dalam tata hukum dibawahnya, khususnya leptospirosis. Dalam Peraturan Menteri Kesehatan diatur bahwa laboratorium diagnosis diklasifikasikan dalam laboratorium rujukan dan pelaksana. Badan Litbang Kesehatan berfungsi sebagai laboratorium pusat rujukan nasional dan pusat kerjasama laboratorium penyakit infeksi new-emerging dan re-emerging.

\section{Konsep Penguatan One Health dan Jejaring dalam Deteksi Dini Leptospirosis}

Pada penularan leptospirosis, bakteri Leptospira patogenik menginfeksi hewan dan manusia, dimana bakteri ini memiliki ekosistem yang sama untuk hidup dan bersirkulasi. Upaya salah satu sektor saja tidak dapat mencegah atau menanggulangi penyebaran leptospirosis. Pendekatan 'One Health' atau lintas sektor dalam penanggulangan leptospirosis diperlukan, termasuk jejaring laboratorium ini diharapkan bisa didapatkan informasi lebih cepat terkait penegakan diagnosis kasus leptospirosis. Berikut skema model One Health dalam deteksi dini leptospirosis, mengadopsi dari teori One Health.

Definisi lima langkah proses prioritisasi deteksi dini leptospirosis dengan pendekatan One Health di atas antara lain :

1. Langkah pertama, targetkan lintas terkait leptospirosis untuk hadir dalam satu kegiatan One Health leptospirosis antara lain Dinas Kesehatan, Puskesmas, Petugas Laboratorium (puskesmas dan RS), Dinas Peternakan, Dinas Pertanian.

2. Langkah kedua, berdasarkan pertemuan One Health tersebut sepakati kriteria untuk deteksi dini leptospirosis dari lintas sektor. Dalam hal ini terdapat integrasi data lintas sektor yang dapat dijembatani melalui komunikasi via media sosial ataupun surat elektronik.

3. Langkah ketiga, berdasarkan pertemuan One Health tersebut disepakati pertanyaan apa saja yang mengacu deteksi dini leptospirosis sehingga diperoleh kriteria deteksi dini leptospirosis lintas sektor berdasarkan kriteria dan pertanyaan yang dikembangkan tadi kemudian diolah dengan metode kualitatif untuk menyepakati kriteria prioritas deteksi dini leptospirosis

4. Langkah keempat, beri peringkat kriteria deteksi dini leptospirosis dengan metode kuantitatif

5. Langkah kelima, finalisasi kriteria deteksi dini leptospirosis yang disepakati dijalankan oleh semua lintas sektor.

Penguatan konsep One Health di atas akan sangat bergantung pada komitmen lintas sektor dalam menjalankan kesepakatan One Health tadi, oleh karenanya payung peraturan dari Pimpinan daerah sangat diperlukan untuk 
menjaga model konsep ini mulai berjalan. Pada konsep One Health di atas pembentukan jejaring laboratorium termasuk didalamnya, karena hal ini terkait langsung dengan upaya penegakan diagnosis leptospirosis itu sendiri. Adanya jejaring laboratorium One health akan mempercepat penanggulangan leptospirosis melalui deteksi dini patogen leptospirosis.

\section{KESIMPULAN}

Deteksi dan pemeriksaan laboratorium leptospirosis perlu ditingkatkan di Indonesia. Leptospirosis jarang dimasukkan sebagai diagnosis banding dalam anamnese pasien dengan gejala mirip typhoid, demam dengue/demam berdarah dengue atau malaria. Penyakit ini sering mis-diagnosis karena gejala klinis pasien leptospirosis sangat bervariasi, dari infeksi tanpa gejala, sindrom mirip flu, sampai leptospirosis berat dengan keterlibatan multi-organ yang dapat menyebabkan kematian. Pendekatan lima langkah One Health atau lintas sektor dalam deteksi dini leptospirosis sangat diperlukan, termasuk jejaring laboratoriumnya, sehingga diharapkan dapat diperoleh informasi lebih cepat terkait penegakan diagnosis kasus leptospirosis di suatu daerah.

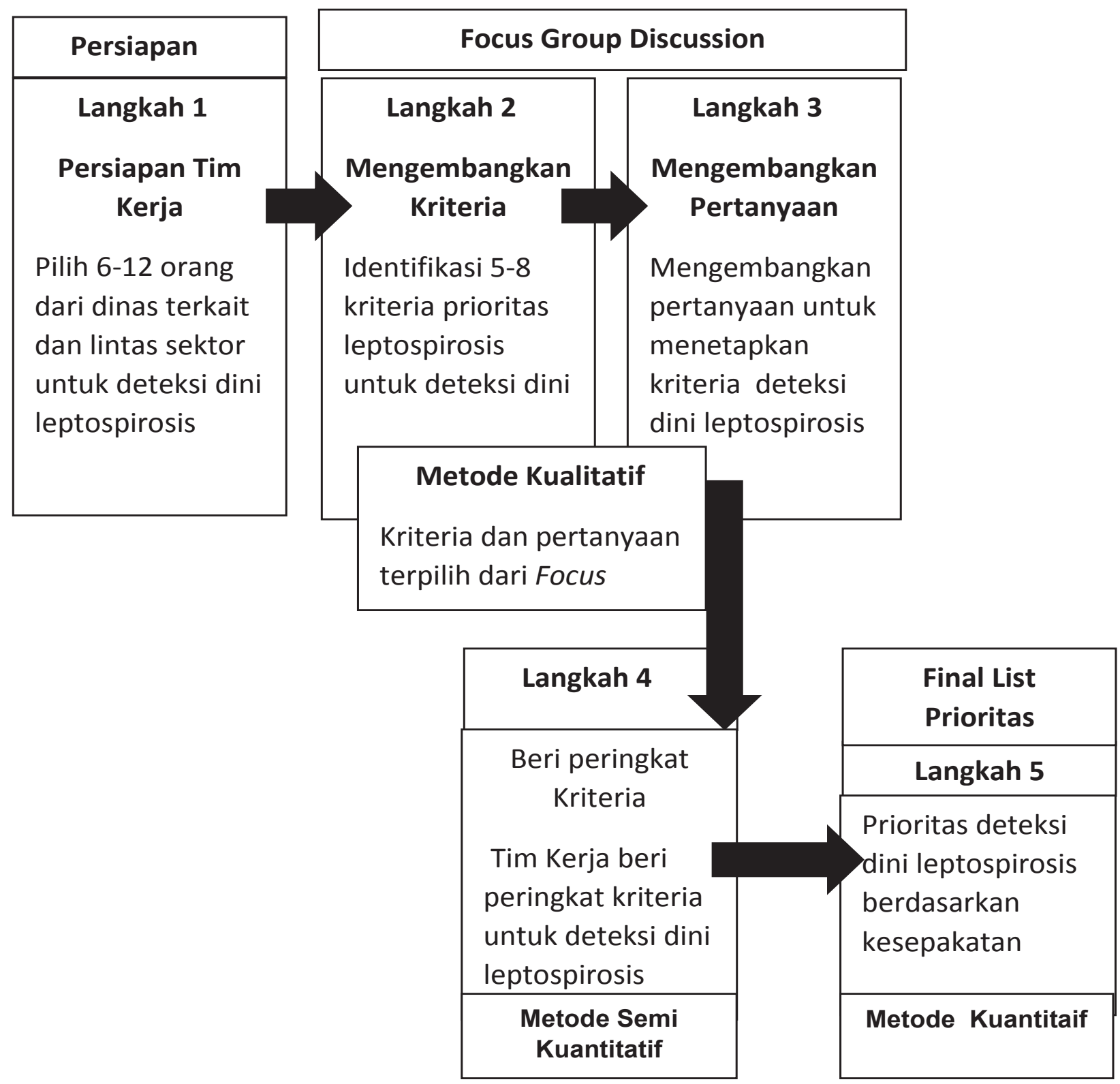

Gambar 3. Lima Langkah Proses Prioritisasi Deteksi Dini Leptospirosis Dengan Pendekatan One Health Dalam Penanggulangan Zoonosis ${ }^{4}$ 


\section{Rekomendasi \\ (Policy Option)}

1. Refreshing dengan cara ceramah klinis leptospirosis dan sharing kasus antar klinisi dan paramedis serta laboratorium pemeriksa perlu dilakukan secara intensif. Leptospirosis dimasukkan sebagi salah satu diagnosis banding selain DBD dan penyakit endemis lainnya.

2. Manajemen integrasi data lintas sektor (Dinas Kesehatan dan Dinas Peternakan dan Pertanian, Kementerian Lingkungan Hidup dan Kehutanan/KLHK, Lembaga Penelitian, dan Perguruan tinggi) dalam kewaspadaan dini dan penanggulangan KLB leptospirosis dikoordinasi oleh Direktorat Jenderal Pencegahan dan Pengendalian Penyakit (P2P) Kementerian Kesehatan.

3. Jejaring laboratorium dan penguatan kapasitas leptospirosis untuk deteksi dini leptospirosis diperlukan. Penguatan surveilans berbasis laboratorium selayaknya dilakukan, sinergis antara KKP, BBTKL, B2P2VRP serta Laboratorium Nasional Jakarta serta UPT di bawah badan litbangkes lainnya.

\section{Keterbatasan}

Beberapa keterbatasan dalam penyusunan kajian leptospirosis ini adalah data primer infeksi pada tikus dari hasil rikhus vektora adalah spot survey. Apabila dilakukan longitudinal survey, tentunya akan memperkaya kajian ini. Data mengenai infeksi leptospirosis pada hewan lain, seperti ternak sapi dan hewan kesayangan yaitu anjing dan kucing yang merupakan potensial inang leptospirosis juga sangat minim, karena belum ada surveilans leptospirosis pada hewan ternak dan hewan kesayangan.

Laboratorium penguji leptospira yang ada saat ini tidak ada garis koordinasi langsung dengan Badan Litbangkes, sehingga komunikasi dan informasi mengenai perkembangan metode laboratorium dalam pemeriksaan leptospirosis sulit dilakukan bila tidak ada wadahnya. Sehingga memang perlu jejaring laboratorium dibentuk dengan koordinator adalah Dirjen Pelayanan Kesehatan dan Dirjen P2P kementerian Kesehatan RI.

\section{UCAPAN TERIMA KASIH}

Terima kasih kami ucapkan kepada Kepala Badan Litbangkes dan Balai Besar Penelitian dan Pengembangan Vektor dan Reservoir Penyakit (B2P2VRP), Para Pakar Rikhus Vektora dan Panitia Pembina Ilmiah (PPI) yang telah memberikan bimbingan dalam pelaksanaan serta penyusunan laporan kajian ini. Terima kasih juga kami sampaikan kepada semua pihak yang telah membantu penyelesaian kajian ini.

\section{Kontribusi Penulis}

FDH sebagai kontributor utama pertama berperan dalam mengkonsep dan menerapkan metodologi, mendraft rancangan awal, menulis, dan melakukan analisis data. DAP sebagai kontributor utama kedua berperan dalam kurasi data hasil FGD, analisis data, mengedit. WD sebagai kontributor utama ketiga berperan dalam kurasi data FGD, dan mengedit. ASJ sebagai kontributor pendukung pertama berperan dalam kurasi data hasil pemeriksaan patogen pada tikus. $\mathrm{M}, \mathrm{BY}, \mathrm{AS}$, dan N sebagai kontributor pendukung kedua berperan dalam kurasi data serovar patogen tikus. Sedangkan R sebagai kontributor pendukung ketiga berperan dalam mengkaji/ mereview artikel.

\section{DAFTAR RUJUKAN}

1. Adler B, de la Peña Moctezuma A. Leptospira and leptospirosis. Vet Microbiol. 2010 Jan;140(3-4):287-96.

2. Picardeau M. Diagnosis and epidemiology of leptospirosis., Medecine et Maladies Infectieuses. 2013. Vol. $43: 1-9$.

3. Guernier V, Lagadec E, Cordonin C, Le Minter G, Gomard Y, Pagès F, et al. Human Leptospirosis on Reunion Island, Indian Ocean: Are Rodents the (Only) Ones to Blame? PLoS Negl Trop Dis. 2016;10(6):1-27.

4. Cassidy Logan Rist, Carmen Sofia Arriola CR. Prioritizing Zoonoses: A Proposed One Health Tool for Collaborative Decision-Making. PLoS One [Internet]. 2014;(October). Available from: https://doi.org/10.1371/journal.pone.0109986\%0A.

5. Satori AK dan D. Metodologi Penelitian Kualitatif. Bandung: Alfabeta; 2010.

6. Steele SG, Booy R, Mor SM. Establishing research priorities to improve the One Health e ffi cacy of Australian general practitioners and veterinarians with regard to zoonoses : A modi fi ed Delphi survey. One Heal. 2018;6(August):7-15.

7. Picardeau M. Virulence of the zoonotic agent of leptospirosis: Still terra incognita? Nat Rev 
Microbiol. 2017;15(5):297-307.

8. Departemen Kesehatan RI. Pedoman Penanggulangan Leptospirosis di Indonesia. Jakarta, Indonesia: Ditjen P2M dan PLP; 2005.

9. Pusat Data dan Informasi Kementerian Kesehatan RI. Data dan Informasi Profil Kesehatan Indonesia. Jakarta; 2017.

10. Pusat Data dan Informasi Kementerian Kesehatan RI. Data dan Informasi Profil Kesehatan Indonesia 2017. Pusat Data dan Informasi Kementerian Kesehatan. Jakarta; 2018.

11. Widarso, H.S. dan WP. Pedoman Diagnosa dan Penatalaksanaan Kasus Penanggulangan Leptospirosis [Internet]. Jakarta: SubDit Zoonosis,Dirjen P2M dan PL, Kementerian Kesehatan RI; 2003 [cited 2015 Sep 2]. Available from:http://adln.lib.unair.ac.id/files/ disk1/784/gdlhub-gdl-s1-2015-chyntiadeb39190-20.-daft-a.pdf.

12. Setadi B, Setiawan A ED. Leptospirosis. Sari Pediatri. 2013. 15 : 163-7.

13. Priyanto A, Hadisaputro S SL, Gasem H AS. Faktor-faktor risiko yang berpengaruh terhadap kejadian leptospirosis (Studi kasus di Kabupaten Demak). J Epidemiol Univ Diponegoro. 2008;(2-5).

14. Jawetz E, Melnick JL AE, Ed. Medical Microbiology (25th ed). New York: Mc Graw Hill, 2010;.: Mc Graw Hill; 2010. p. 483-7.

15. Agampodi SB, Dahanayaka NJ, Nöckler K, Anne MS, Vinetz JM. Redefining gold standard testing for diagnosing leptospirosis: Further evidence from a well-characterized, flood-related outbreak in Sri Lanka. Am J Trop Med Hyg. 2016;95(3):531-6.

16. Musso D, La Scola B. Laboratory diagnosis of leptospirosis: A challenge. J Microbiol Immunol Infect. 2013;46(4):245-52.

17. Smythe LD, Smith IL, Smith GA, Dohnt MF, Symonds ML, Barnett LJ, et al. A quantitative PCR (TaqMan) assay for pathogenic Leptospira spp. BMC Infect Dis. 2002;2:1-7.

18. Kementerian Kesehatan RI. Laporan Rikhus Vektora Provinsi Sumatera Selatan 2015. Salatiga: Balai Besar Litbang Vektor dan Reservoir Penyakit Salatiga, Badan Litbang Kesehatan; 2015.

19. Kementerian Kesehatan RI. Laporan Rikhus Vektora Provinsi Sulawesi Tengah 2015. Salatiga: Balai Besar Litbang Vektor dan Reservoir Penyakit Salatiga, Badan Litbang Kesehatan; 2015.
20. Kementerian Kesehatan RI. Laporan Rikhus Vektora Provinsi Papua Barat 2015. Salatiga: Balai Besar Litbang Vektor dan Reservoir Penyakit Salatiga, Badan Litbang Kesehatan; 2015.

21. Kementerian Kesehatan RI. Laporan Rikhus Vektora Provinsi Jawa Tengah 2015. Salatiga: Balai Besar Litbang Vektor dan Reservoir Penyakit Salatiga, Badan Litbang Kesehatan; 2015.

22. Kementerian Kesehatan RI. Laporan Rikhus Vektora Provinsi Lampung 2016. Salatiga: Balai Besar Litbang Vektor dan Reservoir Penyakit Salatiga, Badan Litbang Kesehatan; 2016.

23. Kementerian Kesehatan RI. Laporan Rikhus Vektora Provinsi Maluku 2016. Salatiga: Balai Besar Litbang Vektor dan Reservoir Penyakit Salatiga, Badan Litbang Kesehatan; 2016.

24. Kementerian Kesehatann RI. Laporan Rikhus Vektora Provinsi Maluku Utara 2016. Salatiga: Balai Besar Litbang Vektor dan Reservoir Penyakit Salatiga, Badan Litbang Kesehatan; 2016.

25. Kementerian Kesehatan RI. Laporan Rikhus Vektora Provinsi Kalimantan Barat 2016. Salatiga: Balai Besar Litbang Vektor dan Reservoir Penyakit Salatiga, Badan Litbang Kesehatan; 2016.

26. Kementerian Kesehatan RI. Laporan Rikhus Vektora Provinsi Sulawesi Utara 2016. Salatiga: Balai Besar Litbang Vektor dan Reservoir Penyakit Salatiga, Badan Litbang Kesehatan; 2016.

27. Kementerian Kesehatan RI. Laporan Rikhus Vektora Provinsi Bangka Belitung 2016. Salatiga: Balai Besar Litbang Vektor dan Reservoir Penyakit Salatiga, Badan Litbang Kesehatan; 2016.

28. Kementerian Kesehatan RI. Laporan Rikhus Vektora Provinsi Sulawesi Tenggara 2016. Salatiga: Balai Besar Litbang Vektor dan Reservoir Penyakit Salatiga, Badan Litbang Kesehatan; 2016.

29. Kementerian Kesehatan RI. Laporan Rikhus Vektora Provinsi Nusa Tenggara Barat 2016. Salatiga: Balai Besar Litbang Vektor dan Reservoir Penyakit Salatiga, Badan Litbang Kesehatan; 2016.

30. Kementerian Kesehatan RI. Laporan Rikhus Vektora Provinsi Nusa Tenggara Timur 2016. Salatiga: Balai Besar Litbang Vektor dan Reservoir Penyakit Salatiga, Badan Litbang Kesehatan; 2016. 
31. Kementerian Kesehatan RI. Laporan Rikhus Vektora Kalimantan Selatan 2016. Balai Besar Litbang Vektor dan Reservoir Penyakit Salatiga, Badan Litbang Kesehatan; 2016.

32. Kementerian Kesehatan RI. Laporan Rikhus Vektora Jawa Timur 2016. Salatiga: Balai Besar Litbang Vektor dan Reservoir Penyakit Salatiga, Badan Litbang Kesehatan; 2016.

33. Kementerian Kesehatan RI. Laporan Rikhus Vektora Jawa Barat 2016. Salatiga: Balai Besar Litbang Vektor dan Reservoir Penyakit Salatiga, Badan Litbang Kesehatan; 2016.

34. Kementerian Kesehatan RI. Laporan Rikhus Vektora Banten 2016. Salatiga: Balai Besar Litbang Vektor dan Reservoir Penyakit Salatiga, Badan Litbang Kesehatan; 2016.

35. Kementerian Kesehatan RI. Laporan Rikhus Vektora Sumatera Barat 2016. Salatiga: Balai Besar Litbang Vektor dan Reservoir Penyakit Salatiga, Badan Litbang Kesehatan; 2016.

36. Kementerian Kesehatan RI. Laporan Rikhus Vektora Aceh 2016. Salatiga: Balai Besar Litbang Vektor dan Reservoir Penyakit, Salatiga; 2016.

37. Balai Besar Penelitian dan Pengembangan Vektor dan Reservoir Penyakit. Laporan Rikhus Vektora DIY 2017. Salatiga; 2017.

38. Balai Besar Penelitian dan Pengembangan Vektor dan Reservoir Penyakit. Laporan Rikhus Vektora Papua Barat 2017. Salatiga: Badan Penelitian dan Pengembangan Kesehatan, Kementerian Kesehatan RI; 2017.

39. Balai Besar Penelitian dan Pengembangan Vektor dan Reservoir Penyakit. Laporan Rikhus Vektora Jambi 2017. Salatiga: Badan Penelitian dan Pengembangan Kesehatan, Kementerian Kesehatan; 2017.

40. Balai Besar Penelitian dan Pengembangan Vektor dan Reservoir Penyakit. Laporan Rikhus Vektora Provinsi Sulawesi Selatan Tahun 2017. Salatiga: Badan Penelitian dan Pengembangan Kesehatan, Kementerian Kesehatan; 2017.

41. Balai Besar Penelitian dan Pengembangan Vektor dan Reservoir Penyakit. Laporan Rikhus Vektora Provinsi Riau Tahun 2017. Salatiga: Badan Penelitian dan Pengembangan Kesehatan, kementerian Kesehatan RI; 2017.

42. Kementerian Kesehatan RI. Laporan Rikhus Vektora Bali 2017. Salatiga: B2P2VRP, Badan Litbang Kesehatan; 2017.

43. Balai Besar Penelitian dan Pengembangan Vektor dan Reservoir Penyakit. Laporan
Rikhus Vektora Kalteng 2017. Salatiga: Badan Penelitian dan Pengembangan Kesehatan, Kementerian Kesehatan RI; 2017.

44. Rampengan NH. Leptospirosis. J Biomedik. 2016;8(3):143-50.

45. Gasem MH, Wagenaar JFP, Goris MGA, Adi MS, Isbandrio BB, Hartskeerl RA, et al. Murine typhus and leptospirosis as causes of acute undifferentiated fever, Indonesia. Emerg Infect Dis. 2009;15(6):975-7.

46. Lokida D, Budiman A, Pawitro UE, Gasem MH, Karyana M, Kosasih H, et al. Case report: Weil's disease with multiple organ failure in a child living in dengue endemic area. BMC Res Notes. 2016;9(1):1-4.

47. Monahan AM, Callanan JJ, Nally JE. Review paper: Host-pathogen interactions in the kidney during chronic leptospirosis. Vet Pathol. 2009;46(5):792-9.

48. Dietrich M, Wilkinson DA, Soarimalala V, Goodman SM, Dellagi K, Tortosa P. Diversification of an emerging pathogen in a biodiversity hotspot: Leptospira in endemic small mammals of Madagascar. Mol Ecol. 2014;23(11):2783-96.

49. Chaudhry R, Das a, Premlatha MM, Choudhary a, Chourasia BK, Chandel DS, et al. Serological \& molecular approaches for diagnosis of leptospirosis in a tertiary care hospital in north India: a 10-year study. Indian J Med Res. 2013;137(4):785-90.

50. Indonesia MH dan HR. UU No. 18 tahun 2009 tentang Peternakan dan Kesehatan Hewan. 2009;1-18.

51. Indonesia MH dan HR. Perpres RI No. 30 Tahun 2011 tentang Pengendalian Zoonosis. 2011;1-11.

52. Indonesia KK, Republik. Permenkes No. 1501 Tahun 2010. 2010;(879):2004-6.

53. Kementerian Kesehatan. Permenkes No.5 Tahun 2014. Jakarta : Kementerian Kesehatan. 2014.

54. Zoonosis SD. Pedoman Diagnosa dan Penatalaksanaan Kasus Penanggulangan Leptospirosis di Indonesia [Internet]. Widarso HS, Dr.MSc.M.Husein Gassem, DR, SpD. Drh. Wilfred Purba, MM, M.Kes.Tato Suharto, SKM.Drh. Siti Ganefa ME, editor. Jakarta: Dirjen P2M, Kementerian Kesehatan; 2003. Available from: https://id.123dok.com// document/ozlo866z-pedoman-diagnosa-danpenatalaksanaan-kasus-penanggulanganleptospirotsi-di-indonesia.html. 